\title{
Analysis of the relationship between nutrition and cancer: Gastronomic options for prevention
}

Judit Molnár ${ }^{1}$ and Mahendra Pal ${ }^{2 *}$

${ }^{1}$ Dietitian, MSc in Food Safety and Quality Engineering; Ph.D. in Food Sciences -Palánkutca, Mosonmagyaróvár, Hungary.

${ }^{2}$ Narayan Consultancy on Veterinary Public Health and Microbiology- Anand, Gujarat, India.

*Corresponding author: Mahendra Pal, Narayan Consultancy on Veterinary Public Health and Microbiology- Anand, Gujarat, India.

Received date: May 17, 2021; Accepted date: May 24, 2021; Published date: June 01, 2021

Citation: Molnár J., and Pal. M (2021). Analysis of the relationship between nutrition and cancer: Gastronomic options for prevention. J. Nutrition and Food Processing, 4(4); DOI:10.31579/2637-8914/054

Copyright: (C) 2021, Mahendra Pal, This is an open access article distributed under the Creative Commons Attribution License, which permits unrestricted use, distribution, and reproduction in any medium, provided the original work is properly cited.

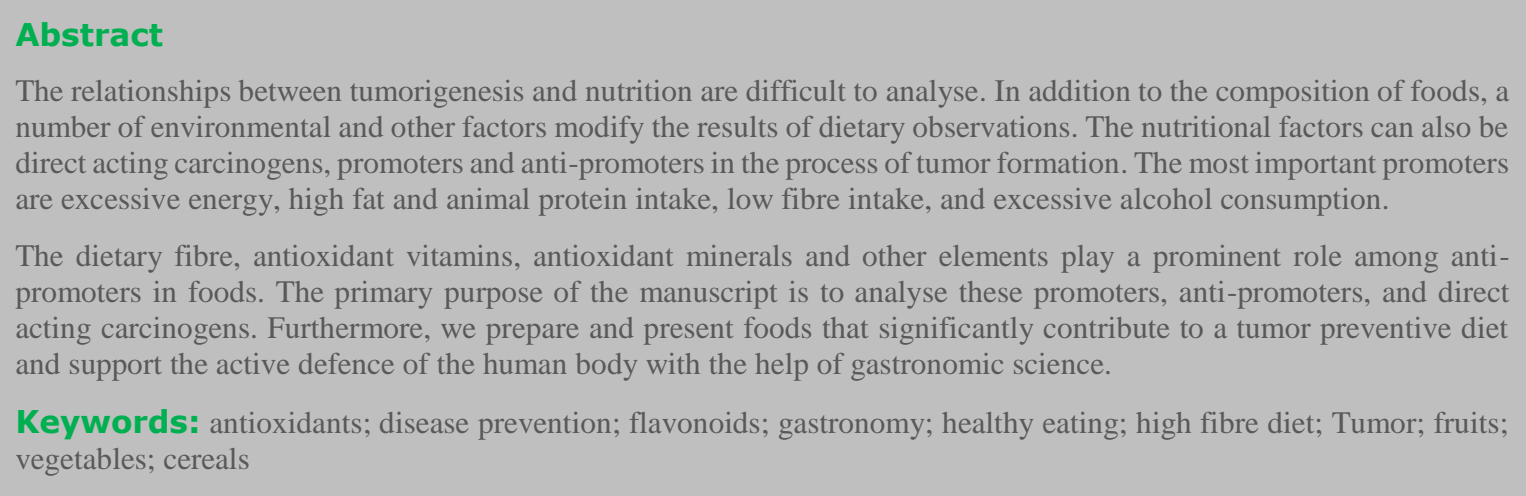

\section{Introduction}

The relationship between tumors and nutrition is still difficult to elucidate today as several factors influence the results of dietary observations [1]. On the one hand, nutritional factors can be direct-acting carcinogens. These food components have direct carcinogens effect or they become carcinogenic through metabolism-function [2]. On the other hand, some nutritional factors may accelerate the formation of tumor and thus may be promoters. Such a promoter effect is caused by excessive energy, high fat, high protein or low fibre intake, and excessive alcohol consumption [3]. In addition, the nutritional factors may be anti-promoters. Anti-promoters protectively influence the process of tumor formation. Among them, dietary fibres, antioxidant vitamins (vitamins A, C and E), antioxidant minerals (selenium, zinc, and iron) are of the greatest importance [4]. As a primary part of our manuscript, we examined the relationship between cancer and nutritional factors. We then used the gastronomy science to make and present dishes. The active ingredients found in these foods (fibre, vitamins, minerals) can be considered as anti-promoters of tumor formation. Thus, they make a great contribution to the health protection and the prevention of the development of cancer.

Direct acting carcinogens, promoters and anti-promoters as nutritional factors in the process of tumor formation

Direct acting carcinogens: Direct acting carcinogens directly exert a carcinogenic effect or become carcinogenic through metabolism in the body. It needs attention due to its carcinogenic effects for example: safrole, polycyclic carbohydrates, aflatoxin, and nitrosamines [5].

\section{Promoters: accelerate the process of tumor formation}

1. Excessive energy intake: Epidemiological studies suggest a positive correlation between obesity and tumorigenesis. Obesity appears as a risk factor for gastrointestinal and gynecological tumors. Therefore, it is recommended to exclude active sports activities and foods with excessive energy from the diet [6].

2. High fat intake: Fats play the biggest role in increasing tumor risk. High fat intake is associated with increased animal protein intake. This manifests itself as an increased risk of tumor formation. The consumption of omega- 3 fatty acids has been associated with a lower incidence of tumors. The dietary recommendations are more about consuming the low-fat products [7].

3. High animal protein intake: The intake of proteins is also essential for the human body. It is recommended to pay attention to limiting their quantitative intake. In addition, preference should be given to low fat protein sources [7].

4. Low fibre intake: Slowed intestinal passage and abnormally concentrated stool play a role in the development of gastrointestinal tumors. Therefore, whole grains, vegetables, and fruits are beneficial in supplementing a high fibre diet [8].

Anti-promoters: protective substances in the tumorigenesis process 
1. Vegetable fibre: The beneficial effects of a high fibre diet $(40 \mathrm{~g}$ / day) have been presented in several publications. The vegetables, fruits, and whole grains help to increase fibre intake and prevent the cancer [9].

2. Antioxidant vitamins: Certain vitamins like A, C, and E play the most significant role in anti-tumor protection as they are antioxidant vitamins [10].

3. Antioxidant minerals: Antioxidant minerals, such as selenium, zinc, calcium, magnesium, iron, copper, iodine, and molybdenum can also be classified as protective substances. In addition to antioxidant minerals, there are also important ingredients for the cancer prevention. These include, for example, flavonoids. The functional properties of flavonoids are enhanced by the consumption of the fruits, vegetables, and cereals [10].

\section{Reducing the risk of tumor with diet}

We prepare and present foods that contribute to the prevention of tumor in remainder part of the manuscript (Figures 1-5).

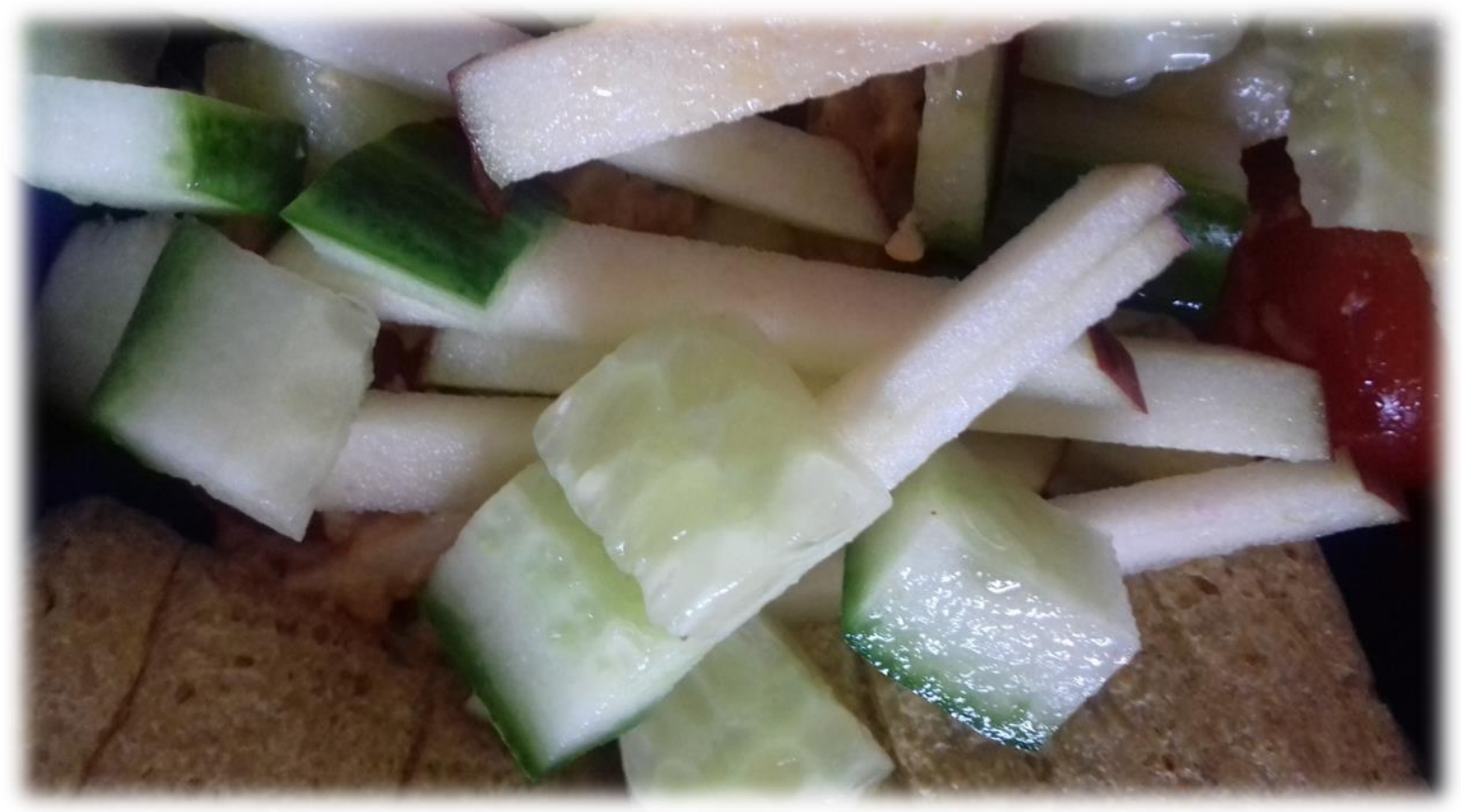

Figure 1. Mixed vegetable salad with salmon cream (Own recipe)

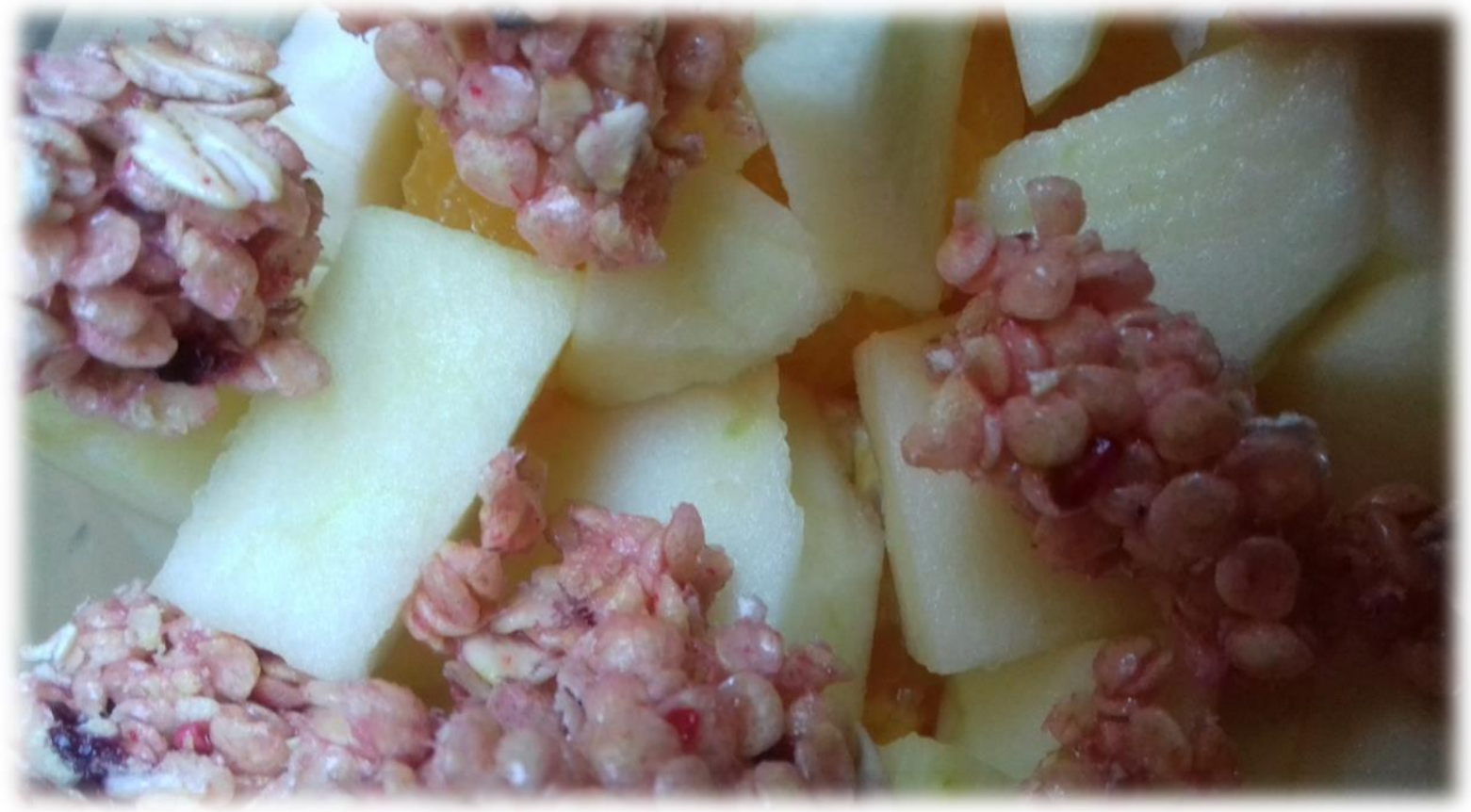

Figure 2. Fruit salad with muesli (Own recipe) 


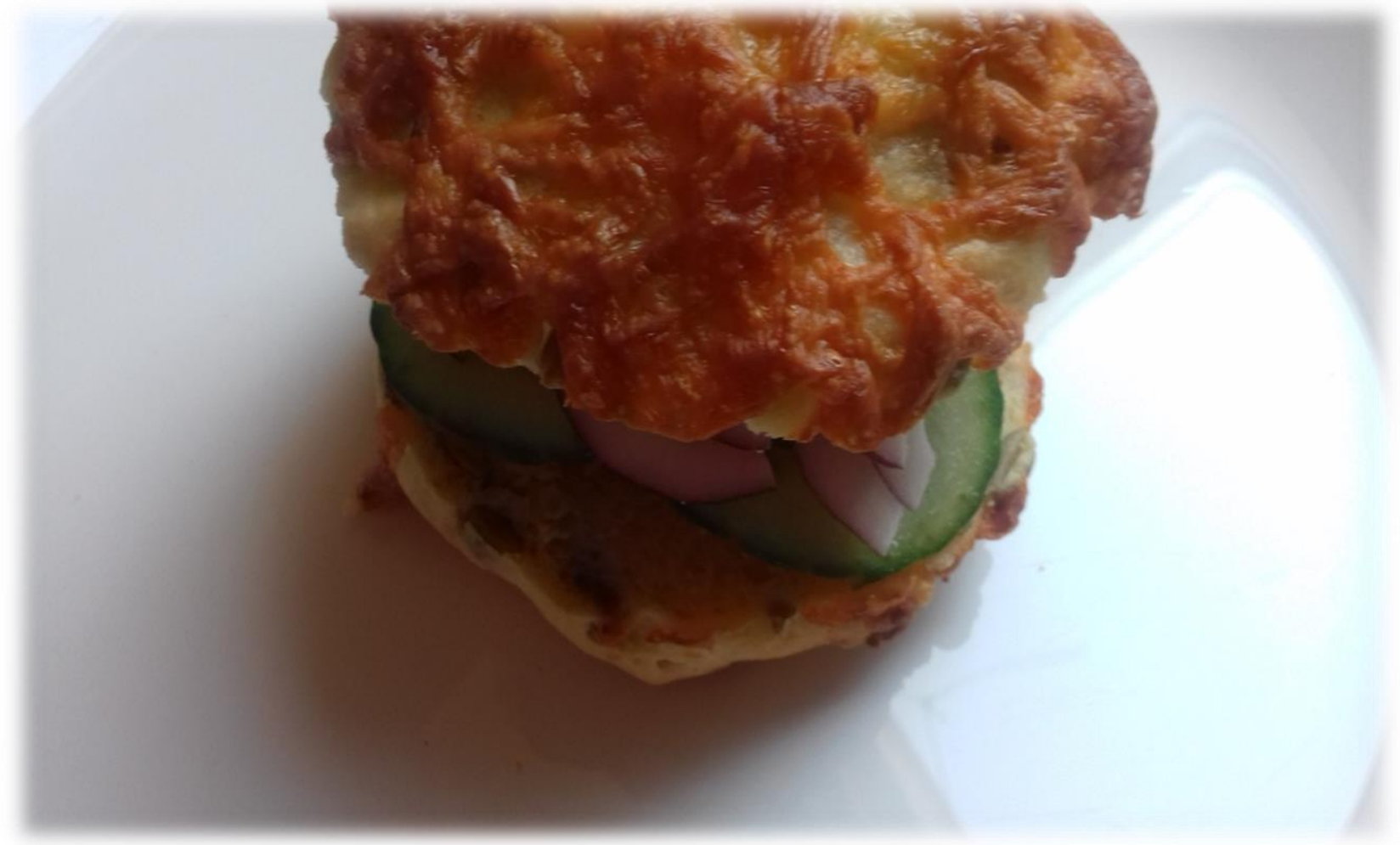

Figure 3. Chicken, vegetables and homemade baked goods with kefir garlic sauce (Own recipe)

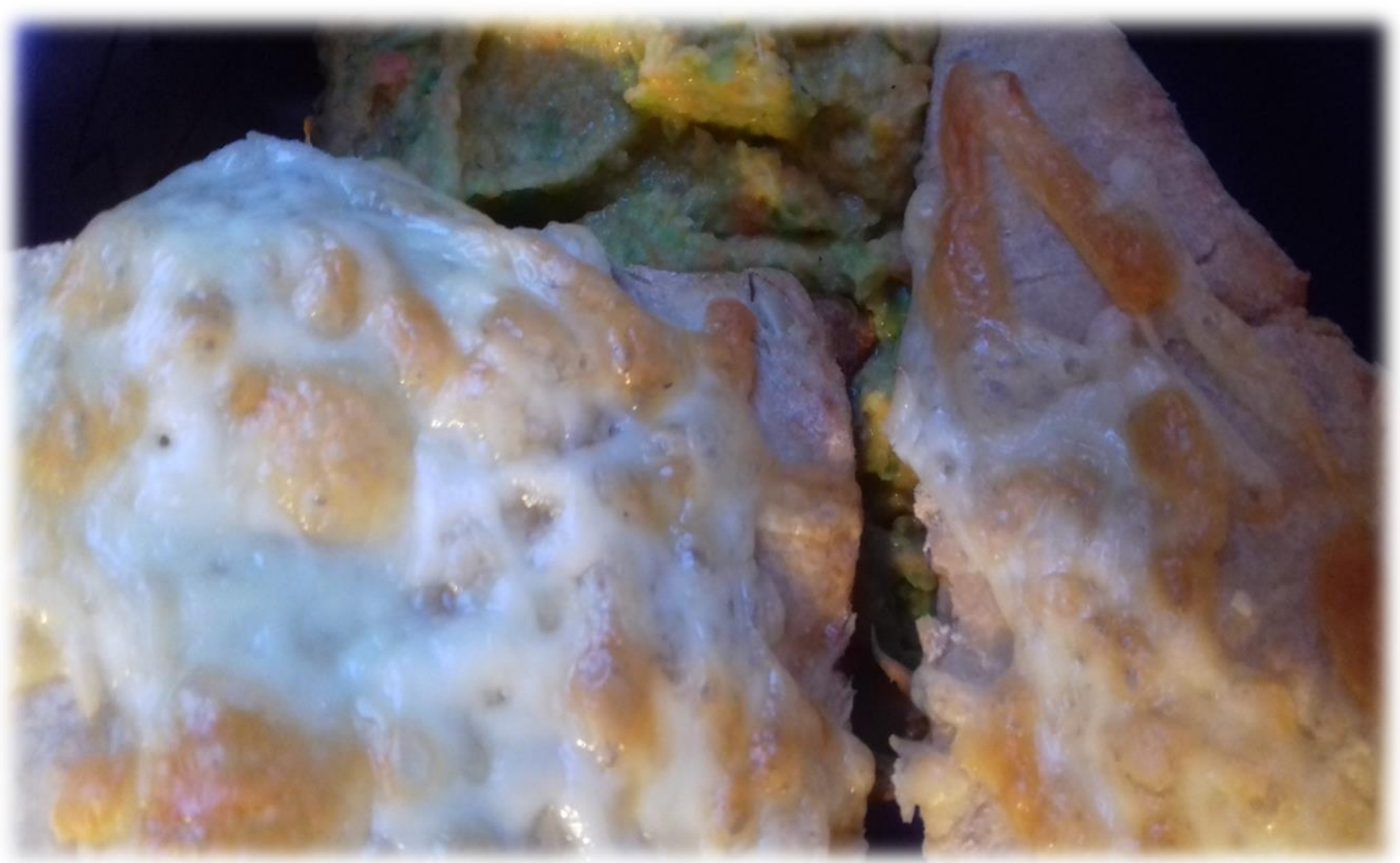

Figure 4. Homemade rye baked goods with vegetable cream (Own recipe) 


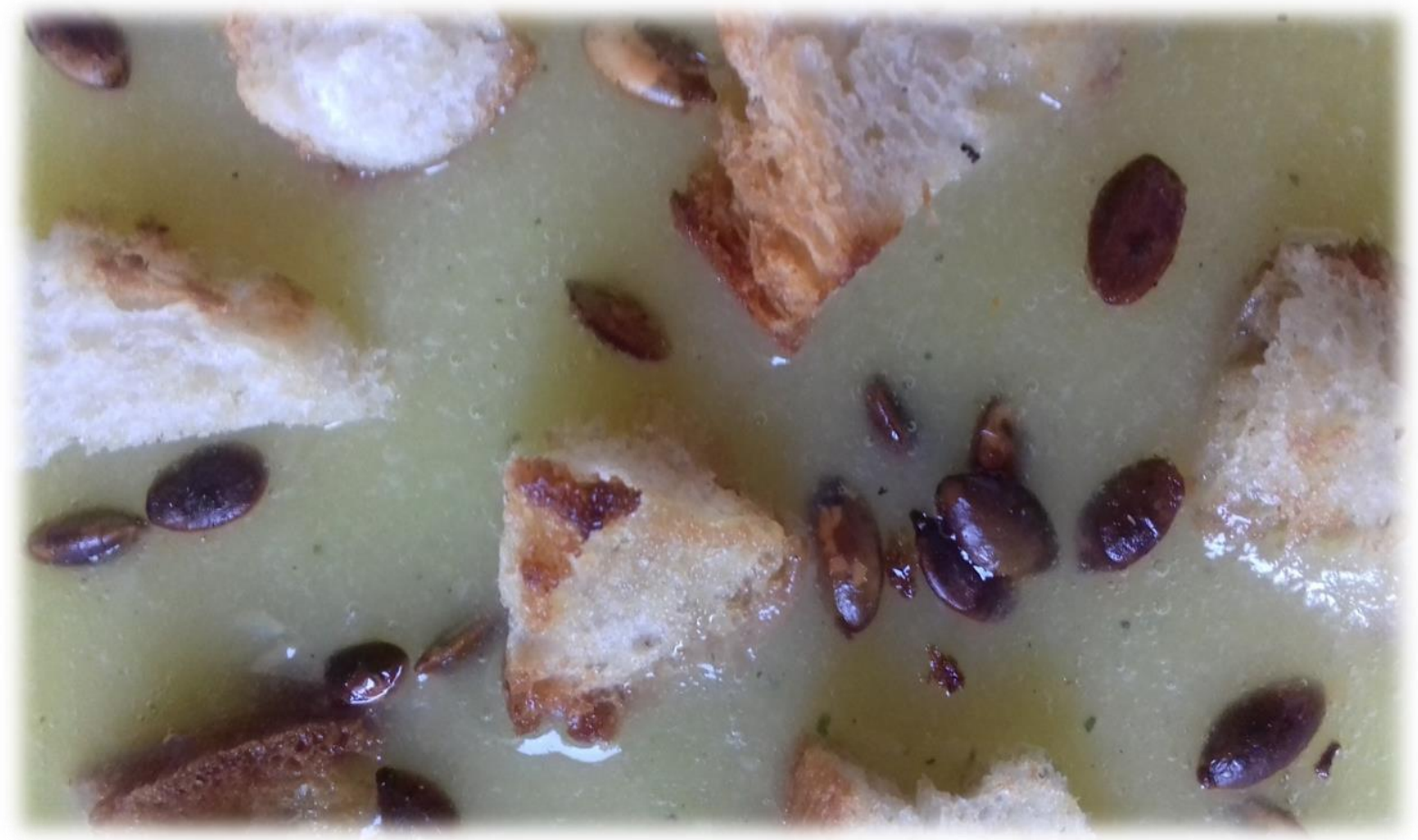

Figure 5. Zucchini cream soup with whole meal toast (Own recipe)

\section{Conclusion}

The relationship between tumor formation and nutrition is difficult to prove due to environmental and other effects. Direct acting carcinogens and promoters (high energy, fat, and protein intake, excessive alcohol, and salt intake, exercise and fibre poor lifestyle) may play a role in the formation of tumor. Furthermore, tumors have anti-promoters as well (high fibre diet, antioxidant vitamins, and minerals, flavonoids). We examine the role of these nutritional factors in the process of tumor formation. Furthermore, we prepared and presented anti-tumor meals. We provide useful practical information to the scientific community; and it is hoped that information contained in this manuscript can also improve their health.

\section{Acknowledgements}

The authors are very thankful to Prof Dr. R. K. Narayan for his suggestions during the preparation of manuscript and Anubha Priyabandhu for computer help.

\section{Contribution of authors}

All the authors contributed equally. They read the final version, and approved it for the publication.

\section{Conflict of interest}

The authors declare that they do not have conflict of interest.

\section{Source of financial grant}

There was no financial support for this manuscript.

\section{References}

1. Sullivan S E, Rice N, Kingston E, Kelly A, Reynolds J V, Feighan J, Power D G, Ryan A M (2021): A national survey of oncology survivors examining nutrition attitudes, problems and behaviours, and access to dietetic care throughout the cancer journey. Clinical Nutrition ESPEN.41: 331-339.

2. Kobets T, Williams G M (2019): Review of the evidence for thresholds for DNA - Reactive and epigenetic experimental chemical carcinogens. Chemico- Biological Interactions.301:88-111.

3. Lee E, Zhu J, Velazquez J, Bernardo R, Gracia J, Rovito M , Hines R B (2021): Evaluation of diet quality among American adult cancer survivors: Results from 2005-2016 National Health and Nutrition Examination Survey. Journal of the Academy of Nutrition and Dietetics.121:217-232.

4. Haskins C P, Champ C E, Miller R, Vyfhuis M A L. (2020): Nutrition in cancer: Evidence and equality. Advances in Radiation Oncology.5:817-823

5. Schrenk D (2018): What is the meaning of 'A compound is carcinogenic'? Toxicology Reports.5:504-511.

6. Bye A, Meli K, Solheim T S, Laird B, Kaasa S, Stene G B, Balstad T R (2019): Food intake by patient generated subjective global assessment (PG-SGA) corresponds to energy and protein intake as well as weight change in patients with advanced cancer. Clinical Nutrition Experimental.25:20-28.

7. Genkinger $\mathrm{J} \mathrm{M}, \mathrm{Wu} \mathrm{K}$, Wang M, Albances D, Black A, van den Brandt P A, Burke K A, Cook M B, Gapstur S M, Giles G G, Giovannucci E, Goodmann G G, Goodman P J, Hakansson N, Key T J, Mannisto S, Marchand Le L, Liao L M, Maclnnis R J, Neuhouser M L, Platz E A, Sawada N, Schenk J M, Stevens V L, Travis R C, Tsugane S, Visvanathan K, Wilkens L R, Wolk A, Smith-Warner S A (2020): Measures of body fatness and high in early and mid-to-late adulthood and prostate cancer: risk and mortality in the pooling project of prospective studies of diet and cancer. Annals of Oncology.31:103-114.

8. Croisier E, Brown T, Bauer J (2021): The Efficacy of dietary fiber in managing gastrointestinal toxicity symptoms in patients with gynecologic cancers undergoing pelvic radiotherapy: A 
systematic review. Journal of the Academy of Nutrition and Dietetics.121: 261-277.e2.

9. Wang G, Zhong D, Liu H, Yang T, Liang Q, Wang J, Zhang R, Thang Y (2021): Water soluble dietary fiber from walnut meal as a prebiotic in preventing metabolic syndrome. Journal of Functional Foods.78:1-14.
10. Chen J, Li Y, Fang G, Cao Z, Shang Y, Alfarraj S, Alharbi S A, Li J,Yang S, Duan X (2021): Green synthesis, characterization, cytotoxicity, antioxidant, and anti-human ovarian cancer activities of Curcumae kwangsiensis leaf aqueous extract green-synthesized gold nanoparticles.
This work is licensed under Creative Commons Attribution 4.0 License

To Submit Your Article Click Here: Submit Manuscript

DOI: $10.31579 / 2637-8914 / 054$
Ready to submit your research? Choose Auctores and benefit from:

* fast, convenient online submission

* rigorous peer review by experienced research in your field

* rapid publication on acceptance

* authors retain copyrights

* unique DOI for all articles

* immediate, unrestricted online access

At Auctores, research is always in progress.

Learn more www.auctoresonline.org/journals/nutrition-and-foodprocessing 